Acta vet. scand. $1973,14,691-699$.

From the State Veterinary Serum Laboratory, Copenhagen, Denmark.

\title{
VACCINATION EXPERIMENTS \\ ON PREGNANT MICE WITH E.COLI VACCINES PREPARED FROM SEPTICAEMIC AND ENTEROPATHOGENIC STRAINS OF E.COLI
}

By

A. Dam

DAM, A.: Vaccination experiments on pregnant mice with E. coli vaccines prepared from septicaemic and enteropathogenic strains of $E$. coli. Acta vet. scand. 1973, 14, 691-699. - Experiments have been carried out with vaccination of pregnant mice against E. coli, followed by i.p. challenge of the of fspring at one week of age.

With a septicaemic strain the results were highly significant, and the method is therefore recommendable for testing of vaccines against such strains of E. coli.

Results were less clear-cut with enteropathogenic strains of $\mathrm{E}$. coli. However, with mortality rates of 40 to $45 \%$ in baby mice born by non-vaccinated mothers and less than $15 \%$ in baby mice born by vaccinated mothers, the difference in percentage mortality seems sufficient to warrant the use of the method also in the control of vaccines against enteropathogenic E. coli strains.

baby mice; E. coli vaccine; potency-test.

In the prophylaxis of colibacillosis in calves and pigs vaccination experiments with $\mathrm{E}$. coli vaccines have been carried through in many countries, in Denmark on calves with vaccines prepared from septicaemic strains of E. coli (Dam 1968), and on piglets with vaccines prepared from enteropathogenic strains (Dam 1971). The present paper deals with attempts to work out a method for testing such vaccines by vaccination of pregnant mice and subsequent i.p. challenge of the baby mice at one week of age. The vaccines tested in this way had been found effective in challenge experiments on, respectively, calves and piglets (Dam 1968, 1971, 1972 and unpublished data), the commercial vaccine also in field trials (Smith 1972). 


\section{MATERIALS AND METHODS}

Vaccines employed: 1) A trivalent E. coli vaccine 015-78-115, $5 \times 10^{9}$ organisms $/ \mathrm{ml}$, with Freund's incomplete adjuvant.

2) A monovalent $E$. coli vaccine 0149 strain $A_{1}, 5 \times 10^{9}$ organisms $/ \mathrm{ml}$, with the incomplete Freund's adjuvant.

3) A different batch of the monovalent E. coli vaccine O149, with the same density.

4) A commercial polyvalent E. coli vaccine, prepared from enteropathogenic strains of E. coli of piglet origin, including serogroup 0149.

Vaccination of pregnant mice: $0.2 \mathrm{ml}$ of vaccine was given s.c. from 3 to 22 , in one case 48 , days before delivery ${ }^{\star}$.

Challenge of baby mice: One week after birth, $0.1 \mathrm{ml}$ of broth culture was given i.p., undiluted or diluted.

\section{RESULTS}

The results of the experiments with a trivalent vaccine of septicaemic strains of E. coli belonging to serogroups 015,078 and $\mathrm{O115}$, are given in Table 1 . The majority of baby mice from non-vaccinated mothers died when challenged with $0.1 \mathrm{ml}$ of a 20 hrs. broth culture diluted $1 / 640$, and $100 \%$ when challenged with $0.1 \mathrm{ml}$ of culture diluted $1 / 160$, while no baby mice from vaccinated mothers died, when challenged with dilutions $1 / 640$, $1 / 320,1 / 160,1 / 80,1 / 40$ or $1 / 20$; about $50 \%$ died when challenged with dilution $1 / 10$ and $100 \%$ when challenged with dilution $1 / 5$.

The outcome of the experiments with pathogenic strains of E. coli is shown in Tables 2 and 3, which give the results of vaccination with two batches of a monovalent E. coli O149 vaccine, and in Table 4, which gives the results of vaccination with a batch of the commercial polyvalent E. coli vaccine. Finally, Table 5 gives the results obtained when the young of mothers vaccinated with a trivalent $E$. coli vaccine prepared from septicaemic strains of E. coli were challenged with an enteropathogenic strain of serogroup 0149 .

From the survey of results given in Table 6 it appears that, with a challenge dose of $0.1 \mathrm{ml}$ of undiluted $20 \mathrm{hrs}$. broth culture

* The author wants to thank dr. Bent Sørensen for his great help in arranging the experiments and for procuring the necessary number of litters of baby mice. 
given i.p., there was a mortality varying from 95 to $100 \%$ in the non-vaccinated groups as well as in the group vaccinated with a heterologous vaccine and from 85 to $93 \%$ in the vaccinated group. With a challenge dose of $0.1 \mathrm{ml}$ of a $20 \mathrm{hrs}$. broth culture diluted $1 / 3$, the mortality in the four non-vaccinated groups and the group vaccinated with a heterologous vaccine was, respectively, 79, 39, 30, 29 and $52 \%$, while in the groups vaccinated with a homologous vaccine it was, respectively, 18, 8 and $7 \%$.

T a b l e 1. Intraperitoneal challenge experiments with strain K 667 (serotype 078: K80) on baby mice from, respectively, vaccinated and non-vaccinated mothers.

\begin{tabular}{llll}
\hline $\begin{array}{l}\text { Number } \\
\text { of young }\end{array}$ & $\begin{array}{c}\text { Days from } \\
\text { vacc. } \\
\text { to birth }\end{array}$ & Challenge dose i.p. & Deaths \\
\hline
\end{tabular}

\begin{tabular}{|c|c|c|c|c|c|c|c|c|}
\hline \multicolumn{9}{|c|}{ Unvaccinated group } \\
\hline 8 & $0.1 \mathrm{ml}$ & 20 & hrs. & broth & culture & dil. & $1 / 20$ & 8 \\
\hline 10 & $"$, & ”, & ” & ” & ” & , & $1 / 40$ & 9 \\
\hline 4 & $"$, & ", & 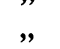 & , & 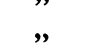 & $"$ & $1 / 80$ & 4 \\
\hline 18 & " " & $"$ & 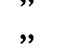 & $"$ & $"$ & , & $1 / 160$ & 18 \\
\hline 8 &, & , & 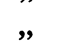 & , & , & , & $1 / 320$ & 7 \\
\hline 12 & $"$ & $"$ & $"$ & $"$ & $"$ & $”$ & $1 / 640$ & 10 \\
\hline 60 & & & & & & & & $\overline{56}$ \\
\hline
\end{tabular}

Vaccinated group

\begin{tabular}{|c|c|c|c|c|c|c|c|c|c|c|}
\hline 1 & 9 & \multicolumn{8}{|c|}{$0.1 \mathrm{ml}$ undiluted $20 \mathrm{hrs}$. broth culture } & 1 \\
\hline 1 & 9 & 0.1 & $\mathrm{ml}$ & 20 & hrs & oroth & ultu & dil. & $1 / 3$ & 1 \\
\hline 3 & 9 & ", & , & ", & ” & ” & ” & ", & $1 / 5$ & 3 \\
\hline 4 & 9 & ", & , & ", & ” & " & ” & ", & $1 / 10$ & 4 \\
\hline 3 & 10 & ” & ” & ", & ” & , & " & ", & $1 / 10$ & 0 \\
\hline 4 & 5 & ", & " & ", & ", & ", & ”, & , & $1 / 20$ & 0 \\
\hline 3 & 10 & ", & " & ", & " & , & ", & ", & $1 / 20$ & 0 \\
\hline 4 & 5 & ", & " & ", & " & ", & $"$ & " & $1 / 40$ & 0 \\
\hline 4 & 16 & ", & ", & ", & $"$ & " & $"$ & " & $1 / 40$ & 0 \\
\hline 4 & 5 & $"$ & ", & ", & $"$ & ", & $"$ & $"$ & $1 / 80$ & 0 \\
\hline 4 & 16 & " & " & ", & $"$ & " & " & ", & $1 / 80$ & 0 \\
\hline 4 & 5 & ", & ", & ", & " & , & $"$ & ", & $1 / 160$ & 0 \\
\hline 4 & 16 & ", & ", & " & " & ", & ", & ", & $1 / 160$ & 0 \\
\hline 4 & 5 & $"$ & " & $"$ & " & ", & ", & ", & $1 / 320$ & 0 \\
\hline 4 & 16 & $"$ & $"$ & $"$ & $"$ & ", & ", & $"$ & $1 / 320$ & 0 \\
\hline 4 & 5 & $"$ & $"$ & $"$ & , & ", & " & " & $1 / 640$ & 0 \\
\hline$\overline{55}$ & & & & & & & & & & 9 \\
\hline
\end{tabular}




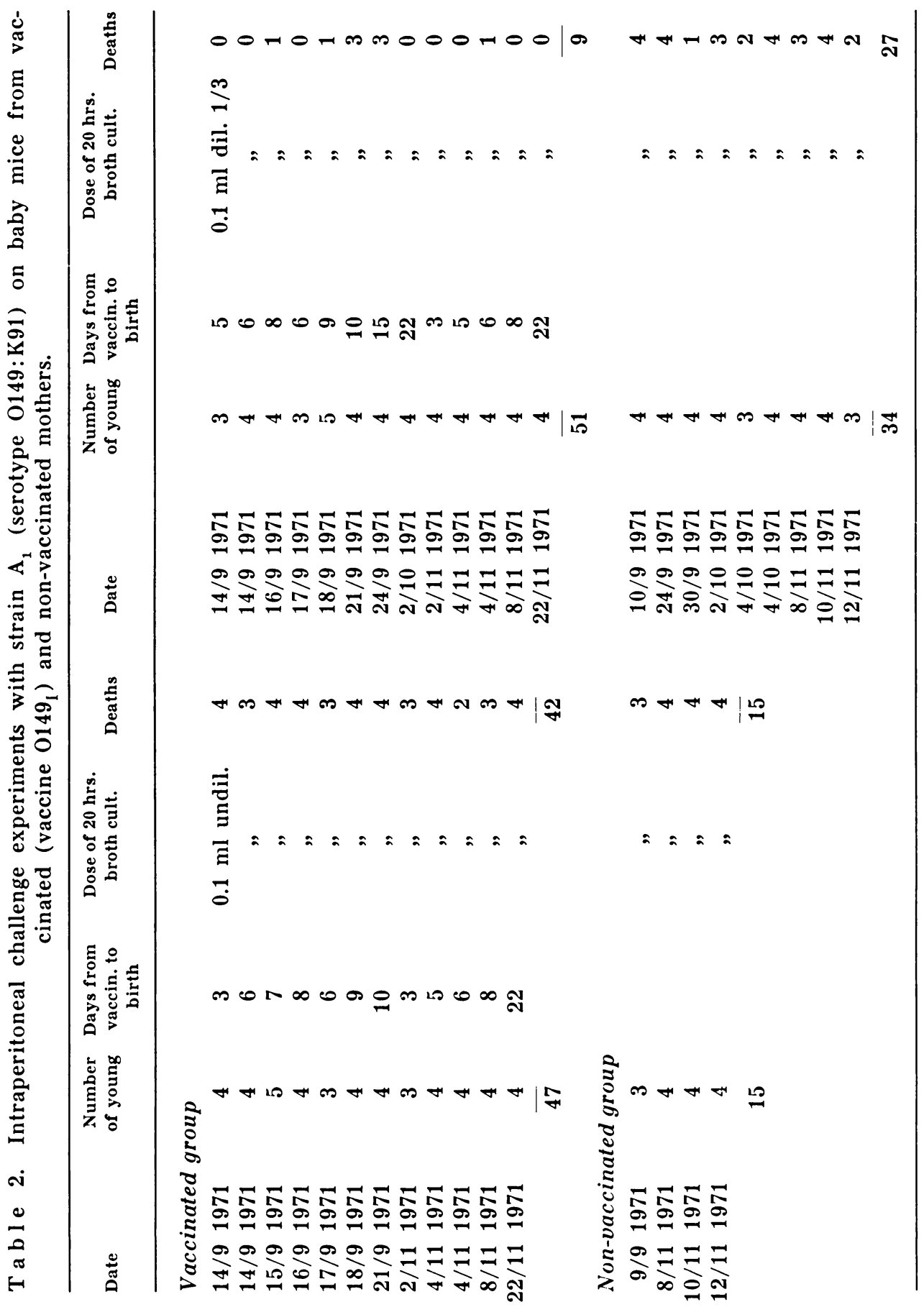




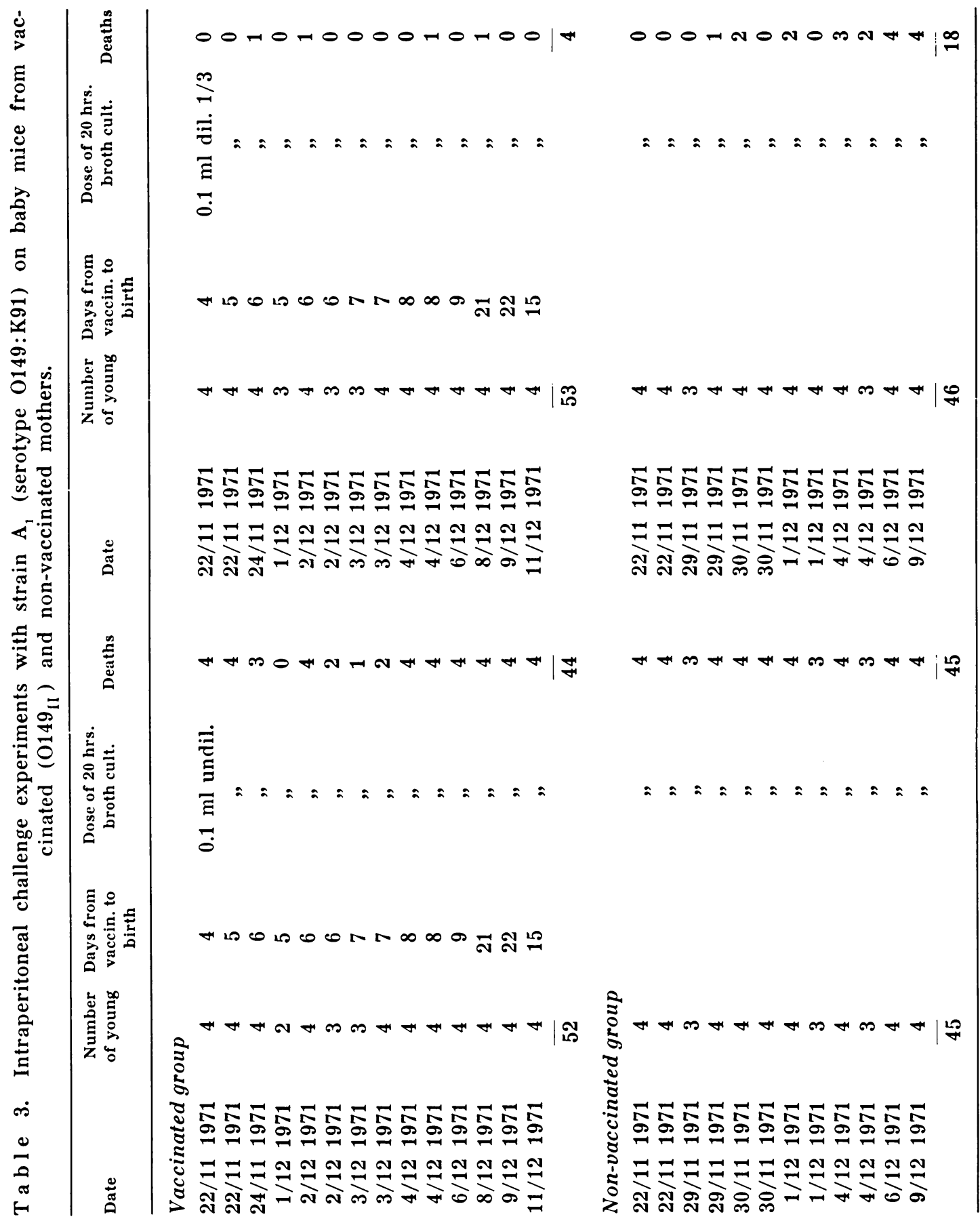




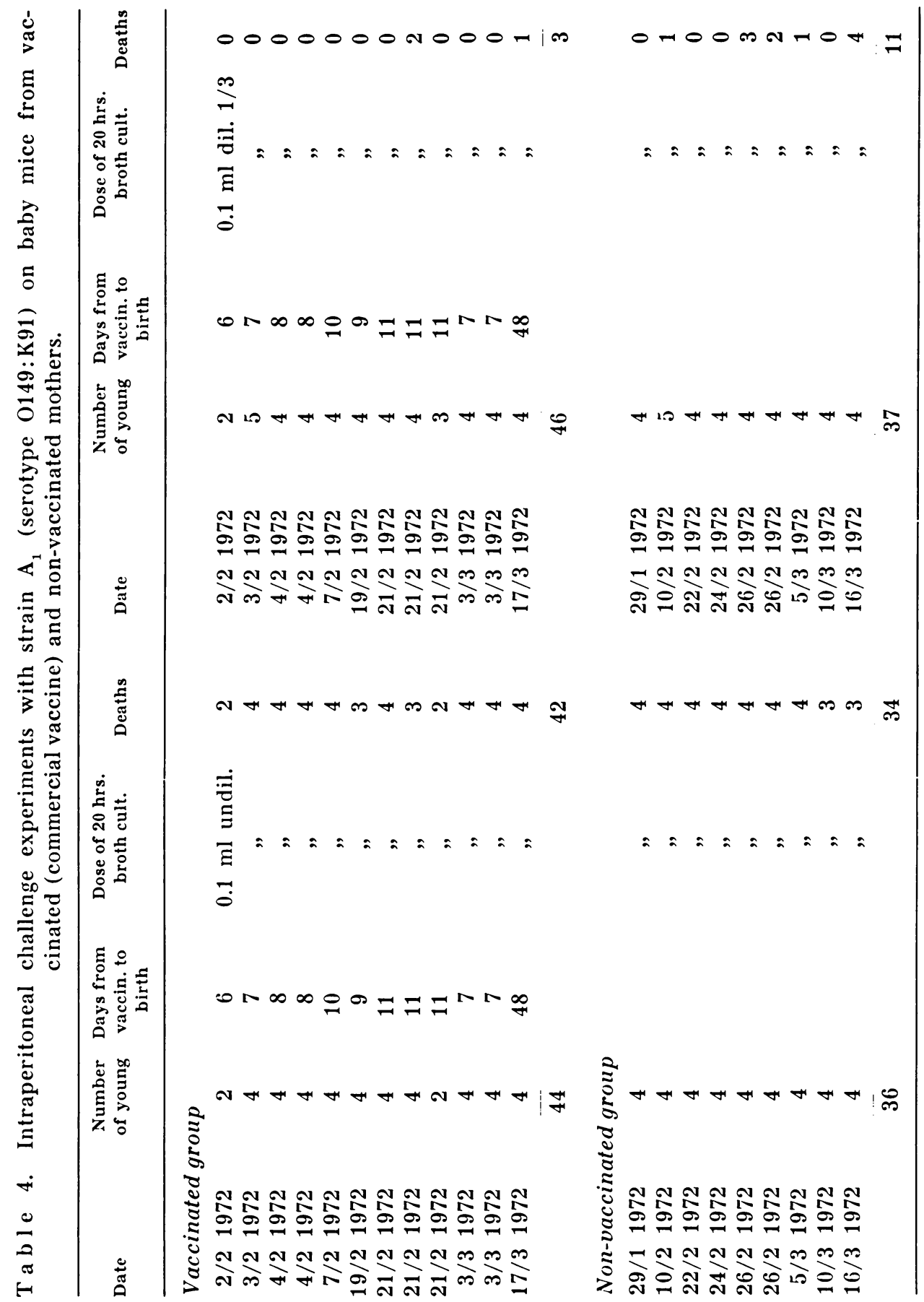




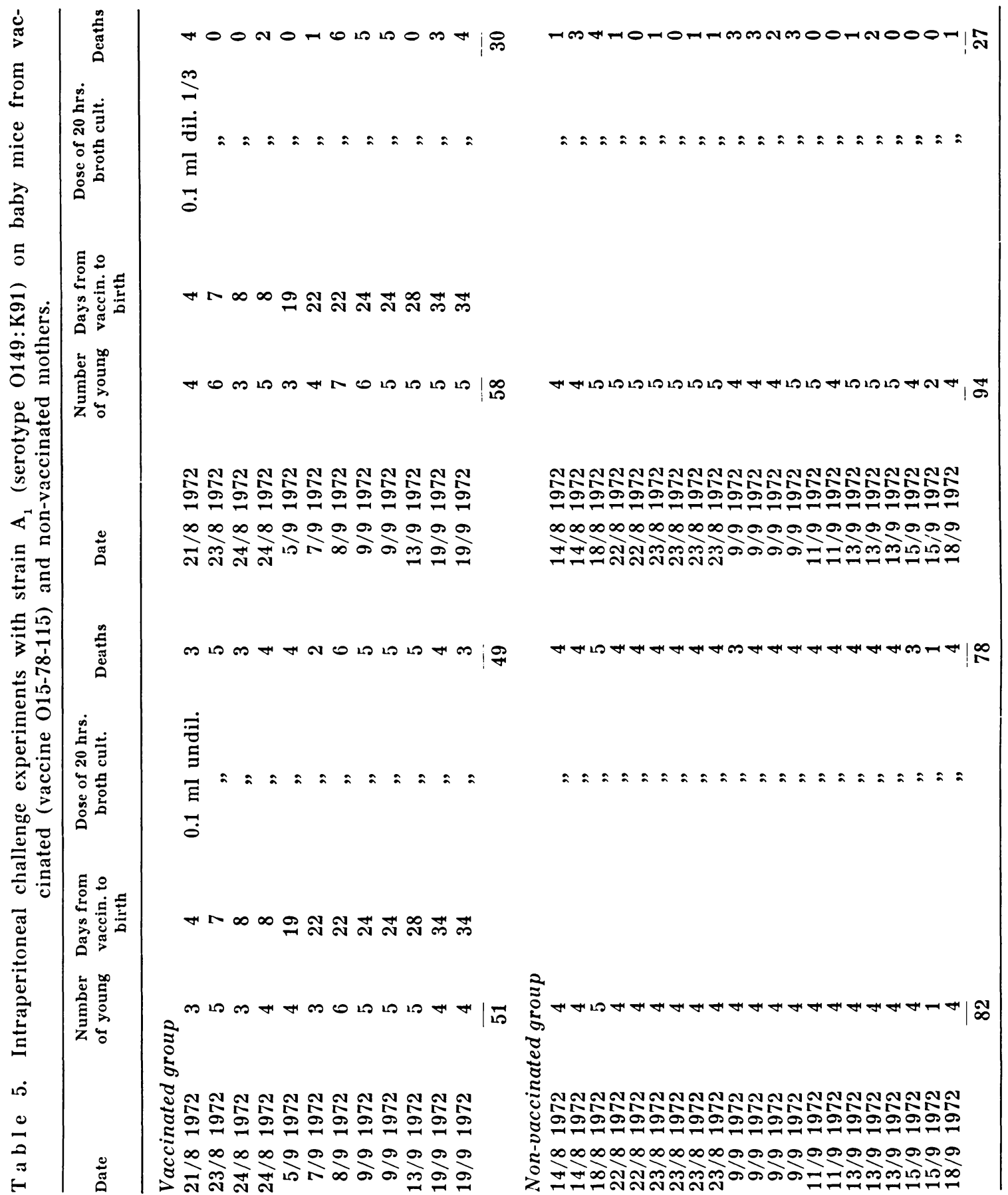


Table 6. Survey of results giving percentage mortality among young of vaccinated and non-vaccinated mothers.

\begin{tabular}{|c|c|c|c|c|c|c|}
\hline \multirow[t]{2}{*}{ Vaccine $0149_{I}$} & \multicolumn{3}{|c|}{ Vaccinated } & \multicolumn{3}{|c|}{ Non-vaccinated } \\
\hline & total & deaths & $\%$ deaths & total & deaths & $\%$ deaths \\
\hline $0.1 \mathrm{ml}$ undil. & 47 & 45 & 92 & 15 & 15 & 100 \\
\hline $0.1 \mathrm{ml} \mathrm{dil.} 1 / 3$ & 51 & 9 & 18 & 34 & 27 & 79 \\
\hline \multicolumn{7}{|l|}{ Vaccine $0149_{I I}$} \\
\hline $0.1 \mathrm{ml}$ undil. & 52 & 44 & 85 & 45 & 45 & 100 \\
\hline $0.1 \mathrm{ml} \mathrm{dil.} 1 / 3$ & 53 & 4 & 8 & 46 & 18 & 39 \\
\hline \multicolumn{7}{|c|}{ Commercial vaccine } \\
\hline $0.1 \mathrm{ml}$ undil. & 44 & 42 & 93 & 36 & 34 & 95 \\
\hline $0.1 \mathrm{ml} \mathrm{dil.} 1 / 3$ & 46 & 3 & 7 & 37 & 11 & 30 \\
\hline \multicolumn{7}{|c|}{ Heterologous vaccine } \\
\hline $0.1 \mathrm{ml}$ undil. & 51 & 49 & 96 & 82 & 78 & 95 \\
\hline $0.1 \mathrm{ml} \mathrm{dil.} 1 / 3$ & 58 & 30 & 52 & 94 & 27 & 29 \\
\hline
\end{tabular}

\section{DISCUSSION}

When baby mice were challenged i.p. with $0.1 \mathrm{ml}$ of undiluted 20 hrs. culture of E. coli $\mathrm{O} 149$, there was no significant difference between litters born by, respectively, vaccinated and non-vaccinated mothers, the mortality varying from, respectively, 85 to $93 \%$ and 95 to $100 \%$. When challenge was made with $0.1 \mathrm{ml}$ of a 20 hrs. broth culture diluted $1 / 3$, the average mortality was from 40 to $45 \%$ among the young of non-vaccinated or heterologously vaccinated mothers, and less than $15 \%$ among the young of homologously vaccinated mothers. This difference would seem to warrant the use of the method in routine testing of E. coli vaccines, provided that the evaluation is based on a sufficient number of litters of baby mice. In a so sensitive test, chance variations may lead to false conclusions if just a few litters are compared. This is apparent from the experiments with vaccine 0149 , (Table 2), in which three mice out of four died in each of the litters $21 / 9$ and 24/9.

With the septicaemic strains of E. coli the mouse test gave highly significant results and thereby proved to be a valuable tool in the efficacy testing of vaccines against E. coli septicaemia.

Whether vaccination takes place in early or late pregnancy seems to be of no influence on the results.

While the present work was being carried out, results of vaccination of mice followed by challenge of the baby mice were 
published from Belgium (Huygelen et al. 1971) as part of a more comprehensive work on immunization of mice against E. coli. However, in the experiments on transfer of passive immunity from vaccinated mice to their offspring, only $E$. coli strains causing systemic disease in calves were included. In these experiments a highly significant protection was obtained, a result which was confirmed in the present experiments. Huygelen's experiments included but one enteropathogenic strain, belonging to serogroup 9, and with this strain just a low degree of protection was obtained.

\section{REFERENCES}

Dam, A.: Prophylaxis of Coli septicaemia in calves by vaccination of the dams. Serological and clectrophoretical studies and calf-inoculation experiments. Proc. 4th Congr. Cattle Diseases, Opatija 1968, 247-253.

Dam, A.: Preliminary experiments on vaccination and serum treatment in the prophylaxis of E. coli O149:K91:H10 infections in newborn piglets. Acta vet. scand. 1971, 12, 457-459.

Dam, A.: The fate of E. coli organisms, strain $A_{1}$, serotype 0149:K91: $\mathrm{H10}$, in newborn piglets from sows immunized with an E. coli 0149 vaccine. Acta vet. scand. $1972,13,140-142$.

Huygelen, C., P. Fasseaux \& Lucia Dobrescu: Immunization of mice against experimental Escherichia coli infection. Zbl. Vet.-Med. B. $1971,18,761-769$.

Smith, S. E. G.: The control of post-weaning E. coli enteritis of pigs using an inactivated adsorbed vaccine. 2nd Congr. Int. Pig vet. Soc., Hannover 1972.

\section{SAMMENDRAG}

Vaccinationsfors $\emptyset$ g på drægtige mus med E. coli vacciner fremstillet ud fra septikæmiske og enteropatogene stammer af E. coli.

Der er gennemf $\varnothing$ rt fors $\emptyset$ ged vaccination af drægtige mus med E. coli vacciner og påfølgende i.p. challenge af afkommet i 7 dages alderen.

Ved fors $\varnothing$ g med septikæmiske stammer fik man udtalt signifikante resultater, og metoden kan derfor anbefales til kontrol med vacciner mod septikæmiske stammer af E. coli.

Resultaterne var mindre udtalte ved fors $\varnothing \mathrm{g}$ med enteropatogene stammer af E. coli. Med en mortalitet på 40-45\% blandt museunger efter uvaccinerede mødre og under $15 \%$ blandt museunger efter vaccinerede mødre synes forskellen i mortalitet tilstrækkelig til at betragte metoden anvendelig også i kontrollen med vacciner mod enteropatogene stammer af E. coli.

(Received August 20, 1973).

Reprints may be requested from: A. Dam, the State Veterinary Serum Laboratory, Bülowsvej 27, DK-1870 Copenhagen V, Denmark. 